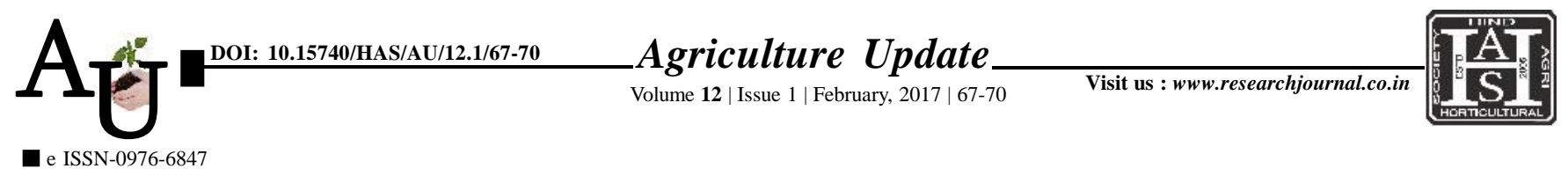

\title{
Rевевсни автісі: Depth-wise distribution of different forms of nitrogen in apple growing soils of Pulwama district of Kashmir Valley
}

\section{SYED SHUJAT HUSSAIN, JAHANGEER A. BABA, MOHD ZUBAIR AND FAYAZ A. MISGAR}

Article Chronicle:

Received :

07.11.2016;

Revised :

19.12.2016;

Accepted :

27.12.2016

KeY Words:

Nitrogen fractions, Profile distribution, Correlation, Accumulation

Author for correspondence :

See end of the article for authors' affiliations
SUMMARY : Depth-wise distribution of different fractions of nitrogen in some selective sites (soil depths) of district Pulwama of Kashmir valley was studied. In all the soil profiles nitrogen fractions (forms) decreased with increase in depth except the fixed $\mathrm{NH}_{4}-\mathrm{N}$ which increased with decreased depth. Organic nitrogen showed high significant positive correlations with total nitrogen $\left(\mathrm{r}=0.987^{* * *}\right)$, organic nitrogen decreased with depth while the fixed $\mathrm{NH}_{4}-\mathrm{N}$ increased and these two fraction were also showed highly significant correlation with each other ( $\left.\mathrm{r}=0.645^{* * *}\right)$

How to cite this article : Hussain, Syed Shujat, Baba, Jahangeer A., Zubair, Mohd and Misgar, Fayaz A. (2017). Depth-wise distribution of different forms of nitrogen in apple growing soils of Pulwama district of Kashmir Valley. Agric. Update, 12(1): 67-70; DOI : 10.15740/HAS/AU/12.1/67-70. 